\title{
A Discussion on the Dilemma and Outlets of Art Education in Higher Vocational Colleges
}

\author{
Pengdong Yuan \\ Department of Art and Design, Jiyuan Vocational and Technical College, \\ Jiyuan City, Henan Province, 454650, China
}

\begin{abstract}
With the development of the world, the society has proposed higher demands on the quality of talents and the competition. In order to improve students' quality, cultivate students' artistic accomplishment and promote their all-round development, higher vocational colleges begin to attach importance to students' aesthetic education. However, resources of higher vocational colleges are limited and the faculty of art education is relatively weak. Therefore, art education in higher vocational colleges have encountered some difficulties. Based on the author's study and work experience, this paper firstly analyzed the function of art education in higher vocational colleges and then discussed the problems and causes of art education. Finally, this paper put forward some countermeasures and suggestions of art education reform in higher vocational colleges.
\end{abstract}

Keywords: Higher vocational colleges; Art education; Dilemma; Countermeasure

\section{Introduction}

Art education plays an important role in the whole education of higher vocational colleges. It is an indispensable part of quality education system. However, with the implementation of enrollment expansion policy in higher vocational colleges, the quality of art education has been declining and some more prominent problems appear. The state's medium- and long-term planning framework for education reform and development (2010 - 2020) has been promulgated and implemented and it is the first medium- and long-term education reform and 
development plan in the 21 st century in our country, which is a programmatic document to guide the current and future national education reform and development. From the perspective of its strategic theme, this plan adheres to the people-oriented and comprehensive quality education. The subject not only becomes the basic trend of education reform, but also the orientation of higher education reform and development. Therefore, although higher education takes professional education as the basic unit, it still has to adhere to the fundamental guideline of quality education. Its goal is to cultivate high-quality professionals with top-notch belief, perseverance, fine character, rich knowledge and innovation[1]. In recent years, vocational colleges have increased the quality education reform in accordance with the outline requirements and increased art education curriculum modules, which takes art appreciation and art skills training as the core to continuously enhance students' aesthetic quality and promote their comprehensive and harmonious development. However, in the course of specific implementation, art education still faces some problems that need to be solved urgently. It is necessary to further change the thinking and intensify the reform so as to promote the sustainable development of art education in colleges and universities.

\section{The Function of Arts Education in Higher Vocational Colleges}

\subsection{Enhancing the aesthetic quality}

Beauty appreciation is the identification and evaluation of beauty. Aesthetic consciousness and aesthetic style determine the level of a person's aesthetic performance. Under the pressure of employment and with the interest-oriented environment, students' materialization concept in vocational colleges is more intense. Art education can help students acquire the basic artistic quality and skills, establish correct aesthetic standards, cultivate elegant artistic taste and artistic accomplishment and improve their humanistic quality by virtue of the deep cultural connotation of art works.

\subsection{Cultivating the spirit of innovation}

The spirit of innovation is to abandon the old ideas and things, and constantly create new ones. In learning and living, students must have transcendental consciousness. They shouldn't be superstitious about books and authority, and should have the courage to break the original restrictions according to facts and thinking, so as to pursue new knowledge and explore new laws and methods[2]. Art courses encourage students to think and conceive from different angles to promote students' imagination and observation, which is an important part of innovative activities. Learning to Survive clearly states: "In the process of innovating the form of art and the sense of beauty, we gain aesthetic experience. This aesthetic and scientific experience are two ways to perceive this eternal world." 


\subsection{Developing good moral sentiments}

We cannot neglect the moral education function of art education. Its purpose is to cultivate students' ability to find things, permeate the noble thought and show beautiful things. Mr. Zong Baihua believes that art education can improve social people's personality. Mr. Cai Yuanpei puts forward that aesthetic education replaces religion. He emphasizes the importance of aesthetic education in cultivation of moral integrity, mind balance and the comprehensive personality. As the professional art education, art education has both instrumentalism and humanism values[3]. Instrumentalism is to carry out art education with utilitarian goals to learn practical art skills, which aims at students' ability in sketching and creation and enhancing their ability of work analysis through the art education.

\section{Problems of Art Education in Higher Vocational Colleges}

\subsection{The lack of interaction}

In the inter-subjectivity theory, inter-subjective cognition is the interaction between subjects through the effective use of empathy means, which means to have consideration for others indirectly to form "our synthesis". The higher the degree that people know each other, the better the teaching effectiveness is. As a type of cultural quality education, art education has its own particularity, which is different from literature, history and natural science. It does not focus on knowledge accumulation, but on students' participation in classroom teaching in all aspects and their exhibition of life experience. It will connect art education with life scenes and make them actively participate into understanding and experience of the works. This requires that teachers take ways different from traditional ones of inheritance of knowledge in art education, so that students can participate in teaching. This will make art teaching classroom atmosphere active and truly reflect students' dominant position, which will make them express true feelings freely. However, in the process of teaching, teachers not only teach students in typical teaching method of knowledge transmission, but also teach the aesthetic theory too much. They interpret art works with the principle of art and make the fine artistic image scientific, which lacks real and free expression between teachers and students. It dilutes effective interaction and exchanges between students and teachers, and the original vivid curriculum image becomes technical system which is difficult to grasp.

\subsection{The lack of emotional resonance}

For non-art specialized college students, art education give them performance of art skills and will evoke the author's aesthetic desires from buildings, folk art, body art and other art forms by appreciating art works, which will make them enjoy art. Due to the diversification of subjectivity and pattern of manifestation of art works, each reader may realize and display different moods based on his own personal experience[4]. He will gradually become a participant in a work of art 
from a bystander. However, in the actual teaching process, teachers often interpret works from their own subjective desire and their own subjective understanding in scientific principle or law. They want to lead students in a common understanding. Although students learn analysis method and skills, it lacks their own internal affection and the works of art with human spirit become a scientific object of observation, which loses inherent emotions of works. For example, for the film and television works of the war times which contains characters and manifestations of that period, we can not purely make beautyappreciation from the view of modern color and filming technology and we should find social value based on the the characteristics of times to experience people's joy and anger at that time .

\subsection{The lack of practical activities}

Works of art are not only the embodiment of aesthetic principles, but also the expression of daily life experience. It is the sentiment and manifestation of life experiences, intelligence and sublimation endowed by nature. Therefore, art theory and work study in class are only one means of curriculum goals. Compared with human aesthetic quality improvement, the classroom teaching ability is limited in innovation spirit and ability training. It is necessary to take various artistic images in life scene as the content of education. It should become the object of students' learning and give students opportunities to imitate and experience in various scenes. In fact, there exists content of practical activities in urban community, campus and individual living space. They all can be included in the scope of practical activities to constantly enrich implicit knowledge. In Polanyi's view, there is a lot of content around us that is acquired through physical senses or rational intuitions, which are not directly expressed in words sometimes, like a small and shining field surrounded by infinite darkness, which gives people more space to explore and imagine[5]. In real education, with following the traditional classroom teaching space and mode, teachers do not attach importance to extra-curricular factors, so it can not become the scene of education and teaching. The lack of practical activities affects students' aesthetic range and limits their perspective, which is not conducive to the development of emotional and innovative thinking.

\section{The Countermeasure and Suggestions of Art Education Reform in Higher Vocational Colleges}

\subsection{Updating the teaching concept and establishing humanistic education orientation}

Humanistic spirit is a kind of custom, life style and social psychology of mankind reflected in constructing various systems, standardizing and producing material products, which is the highest level of the metaphysical part of the culture, including the value pursuit of normal life for maintaining people's normal life, ethics, group consciousness, life passion, way of life and way of thinking. It also 
contains things which promote the development of human society, self-reflection, national spirit and political beliefs. Art education resources contain rich humanistic spirit. The external form of art works different from exploitation of the works of nature contains the creator's delight of life, human feelings, and even the true depiction of life. It may also include the author's broken feelings and life experience. Therefore, art education in higher vocational colleges requires teachers to break the traditional teaching thinking, firmly establish the value orientation of humanistic education and combine with the basic principle of reception aesthetics to overcome the concept of supreme technology. In teaching, teachers should be good at reserving the space of students' association and recreation and guide students into the real life and emotional world of art creators by stirring their inner emotion. Therefore, they will actively experience artistic works and art thoughts to enhance their analysis and understanding of good things, which will arouse students' desire for a better life[6].

\subsection{Promoting the reform of teaching methods and giving full play to students}

We should reform classroom teaching, break the traditional static knowledgetransference mode and optimize the art education and teaching environment. Besides, colleges should strive to create the appropriate opportunities and scenarios, regard students as the main body and fully mobilize students' enthusiasm and initiative to participate in the whole process. This will give more opportunities to students and teachers to express and communicate freely. Teaching environment should give each student space to make free imagination, which allows students to think boldly, even if it is a whimsical. Whether students have the freedom to choose their own learning content is the key whether we can achieve innovative education. Teachers should intentionally set theater scene in teaching and create a pleasant, democratic, relaxing and harmonious atmosphere for students by virtue of the performance of action to trigger a positive psychological reaction. At the same time, for each education theme, teachers should take a variety of teaching methods, so that students can create and perform from multiple angles. This will enhance students' self-confidence in the process of self-expression and improve their innovation. For example, when we appreciate "discus thrower", teachers should give students opportunity to speak actively and express their feelings freely from different views. Therefore, they can fully understand and explain the creators' emotional world.

\subsection{Strengthening the practice direction and establishing all-round diversified classroom}

Mr. Tao Xingzhi, a well-known educator, has always advocated the education thought that life is education and society is school. He proposes the concept of learning and doing all-in-one. These valuable educational thoughts have great guiding significance to art education teaching in higher vocational colleges. In addition to classroom teaching, extracurricular and external art education activities are important part of art education, which is important extension and 
supplement of classroom teaching. We should attach equal importance to the first classroom and the second classroom, and establish a comprehensive and diversified art education classroom. We should be good at carrying out various forms of practical activities, such as animation design activities, campus clothing contest, life scene photography exhibition and bedroom design competition. Besides, we should enrich students' practical experience and enhance students' autonomy and creativity. In particular, we should lead students' the aesthetic feeling of art works to social problems and promote them to combine creative thinking with practical problems. Then, teachers encourage them to propose solutions to these problems creatively. Moreover, we should take advantages of art education factors in the art scene and encourage them to experience and imagine things around them to give play to the city cultural heritage, artistic landscape and school campus design[7]. We may encourage students to express their views based on their usual travel resources. For example, they can share and exchange their experience in Beijing Olympic Sports Center, Shanghai World Expo Park and ancient cultural relics, which will stimulate students' understanding and imagination of culture and art, and cultivate students' innovative thinking and innovative spirit.

\subsection{Enhancing construction of teaching staff and their professional ethics}

Teachers should not only teach students knowledge, but also cultivate people with culture, especially in art education. It is not enough that art education only reflects the humanistic orientation in the top-level design, such as talent cultivation, which can not automatically generate students' humanistic spirit. Therefore, teachers need to play a good intermediary and leading role. If teachers only take imparting the knowledge of art as the teaching goal, the humanistic value that the course contains can not be delivered to students. Therefore, it is necessary to continuously strengthen the construction of teaching staff in higher vocational colleges to form a regular education and learning mechanism for teachers. The construction focuses on learning quality education theory, requires them to enrich and improve the humanistic quality, and supervise them to permeate humanistic quality education in all aspects of teaching with imparting knowledge. At the same time, teachers' professional ethics plays an indispensable and important role in education and teaching. Teachers' sense of responsibility, professionalism and patriotism have a subtle influence on shaping college students' humanistic spirit. Schools should continue to strengthen the professionalism and professional ethics of education, and supervise teachers to guard professional ethics and maintain the image of teachers consciously.

\section{Conclusion}

Art education in higher vocational colleges should adjust contents and forms of basic education in art courses and take the market as the guidance. Moreover, it should reappraise training objectives and direction and change it from teachingoriented form to people-oriented form. This requires schools to pay attention to 
practicing teaching, updating teaching content, adding new knowledge and adopting new technology to impart high-precision and new knowledge, which should be the main content in current college art curriculum. Besides, colleges may make full use of modern media teaching results to optimize teaching and improve teaching quality. Finally, schools should attach importance to students' basic ability and comprehensive quality improvement, and give students space to take the initiative to carry out creative practice. This will realizes the organic integration and unity of artistry and innovation in art education art ultimately.

\section{References}

[1] Zhao Meng. A Discussion on the Art Education Teaching Reform in Higher Vocational Education. Education and Vocation, 27, pp.118-120, 2015.

[2] Li Lianfang. A Research on the Reform and Development of Art Education in Higher Vocational Colleges. China Adult Education, 12,pp.99-100, 2008.

[3] Ma Yanping. A Research on the Reform and Development of Art education in Higher Vocational Colleges. Digital Users, 10,pp.87, 2013.

[4] Yin Weidong. A Discussion on the Status and Reform of Art Education in Higher Vocational Colleges. Art Science and Technology,06,pp. 337, 2013.

[5] Li Zhiwen. A Discussion on Art Education Reform in Higher Vocational Colleges. Beauty and the Times, 01, pp.67-68, 2011.

[6] Zhou He. A Discussion on Art Education in Higher Vocational Colleges. Journal of Education Development, 03, pp.57-58, 2006.

[7] Wang Liyuan. A Discussion on the Development and Reform of Art Education in Higher Vocational Colleges. Electronic Production,15, pp.133, 2014. 